\title{
A INFLUÊNCIA OU “OS BALCÕES SUCESSIVOS SObRE O RIO”, DE RUY BELO
}

Ana Maria Pereira SOARES

\section{Resumo}

Para Ruy Belo, a influência da tradição no poeta tardio é inevitável e aquele que busca a sua singularidade tem de ter consciência desta realidade inescapável. Neste estudo, é analisada a dimensão hipertextual deste autor, incidindo-se sobretudo a atenção sobre "Os balcões sucessivos sobre o rio", composição que introduz o último livro do poeta, Despeço-me da terra da alegria (1977), e que dá continuidade aos processos compositivos e às problemáticas abordadas no magnífico poema longo, A margem da alegria (1974).

Palavras-Chave: Ruy Belo; influência; hipertextualidade; mal.

\section{A SOMBRA DA TRADIÇÃO}

Poema de abertura de Despeço-me da terra da alegria (1977), curiosamente não datado, contrariamente aos restantes que constituem a obra, a composição poemática "Os balcões sucessivos sobre o rio" dá o tom para a leitura do último livro escrito por Ruy Belo, e entretece, ao mesmo tempo, um diálogo subterrâneo com a obra precedente, $A$ margem da alegria ${ }^{1}$, concluída em setembro de 1973.

Poeta e crítico atento, Ruy Belo afirmava ter consumido "anos de vida em páginas de livros [...] em busca de pressupostos teóricos” (2002, p. 320), fundamentais para a sua intervenção na poesia. O

\footnotetext{
* Doutoramento em Estudos Literários, Culturais e Interartísticos, Ramo de Literatura e Cultura - Estética Literária, pela Faculdade de Letras da Universidade do Porto, Porto, Portugal. E-mail: amsoares1819@gmail.com

$1 \quad$ A este propósito, ver SOARES, 2017.
} 
estudo da teorização literária, a reflexão e a observação moldaram o seu pensamento acerca do fenómeno poético e levaram-no à experimentação de caminhos, no sentido de procurar encontrar uma voz própria. Leitor insaciável e esclarecido, este autor revela, na sua escrita, um conhecimento aprofundado dos princípios instituídos por Bakhtine acerca do discurso e mais tarde desenvolvidos por Julia Kristeva ${ }^{2}$. Na verdade, todos os enunciados estão interligados numa complexa rede de relações, reenviando inevitavelmente uns para os outros, independentemente da vontade de quem os cria. No seu artigo As influências em poesia, publicado em 1970, Ruy Belo debruça-se particularmente sobre esta questão. Aí, demarca-se dos críticos incultos e desinformados do seu tempo que negam o princípio da influência, considerando uma poesia menor aquela que revela um diálogo com os discursos do passado ou contemporâneos. As palavras são um património comum, pelo que a influência é uma inevitabilidade da escrita, reitera categoricamente o poeta. Por este motivo, aos críticos ignorantes do fenómeno literário e defensores de uma poesia medíocre e insulsa que nega o seu passado, Ruy Belo lança desafiadoramente: "só o poeta dotado de musa própria pode consentir influências e tantas mais consentirá quanto mais poeta for" (2002, p. 320).

$\mathrm{Na}$ perspetiva do autor do artigo, era fundamental esta lucidez para o poeta tardio. Sobre ele recaía a pesada herança de um passado em que já tudo fora experimentado, tal como proclamava já Horácio na sua Arte Poética. A "pressão dos mortos” (BELO, 2014, p. 261) realça essa impossibilidade de desvinculação das raízes antigas a que inevitavelmente o escritor tardio dá continuidade. O poeta utiliza as palavras de toda a gente, palavras que acusam a sua vulnerabilidade face à ação do tempo, sobrecarregadas de conotações, envelhecidas, manifestando, enfim, o desgaste do uso e do hábito. Nesta perspetiva, e em linha com o pensamento horaciano, Ruy Belo defende que o bom poeta é aquele que, para além do desenvolvimento das suas qualidades naturais, terá de recorrer ao estudo e ao conhecimento aprofundado dos grandes mestres, a

2 Na perspetiva desta teorizadora, "tout texte se construit comme mosaïque de citations, tout texte est absorption et transformation d'un autre texte” (1978, p. 85). 
fim de encontrar um caminho próprio, distinguindo-se dos demais. Assim, apesar de a influência dos textos predecessores surgir como pressão e opressão, consciência que assombra e ensombra o poeta tardio e o impele à necessidade de se situar face a esse passado para definir um caminho próprio que afirme e confirme a singularidade da sua voz, o conhecimento das vozes extintas surge também como um importante ponto de partida para a descoberta de novas formas de dizer o poema, procurando vencer a corrosão das palavras, envoltas pela sedimentação de séculos que lhes desvirtuaram o sabor, os contornos, o brilho primitivo. Para tal, o poeta tardio terá de britar, pulverizar, reduzir aos seus componentes mínimos os discursos predecessores, a fim de que possa ser criado um novo objeto artístico que se afirme pela sua invulgaridade e pelo seu impacto estético.

Não obstante esta necessidade de destruição para se construir novos artefactos, Ruy Belo não deixa de salientar que a influência se constitui como uma "homenagem", uma vez que apenas são eleitos os discursos que despertaram admiração no poeta. Porém, essa escolha tem como principal objetivo, para além da homenagem, o "confronto". Na verdade, será com essas vozes extintas que o poeta tardio tentará arduamente "experimentar as suas forças", procurando ir mais longe e mais alto, buscando um discurso tenso e de elevada voltagem poética, através da violência exercida sobre as palavras.

Leitor atento de T. S. Eliot, Ruy Belo seguiu com rigor os seus pressupostos, no que se refere ao recrutamento do material compositivo. $\mathrm{O}$ bom poeta seria aquele que construiria o seu repertório incidindo a atenção sobre áreas do saber inesperadas e diversificadas, géneros surpreendentes, fontes remotas (ELIOT, s/d, p. 270). A disparidade de materiais recolhidos seria a matéria-prima ideal para a criação poemática, pois a sua imprevisibilidade e estranheza potenciariam, no novo artefacto, elevadas temperaturas da expressão e a consequente emoção estética. A origem desses materiais não teria de ser, contudo, desvendada ao leitor. Ruy Belo defendia a sua plena codificação. A clareza não era um propósito da grande poesia, pelo contrário, deveria ser exigente, criar barreiras, desconcertar, procurar a ambiguidade, obrigando, deste modo, críticos e leitores a uma atitude mais ativa. A morosidade da escrita teria 
de corresponder à conquista igualmente morosa do sentido. Por esta razão, o difícil levantamento das influências é um trabalho que cabe "à crítica, imediata ou científica”, processo que o poeta reconhece como sendo bastante árduo e complexo (2002, p. 284) e que não poderá ser encarado como um fim em si mesmo, mas como o ponto de partida para o reconhecimento da "originalidade" de uma poesia que assumiu a pesada herança do seu passado e procurou encontrar a sua voz própria.

\section{A HiperteXtualidade EM “Os Balcões SUCESSIVOS SObRe O RIO"}

Anos mais tarde, Genette definirá o conceito de hipertextualidade, relação transtextual cuja teorização Ruy Belo não chegará a conhecer. A hipertextualidade distingue-se de outros tipos de transcendência textual pelo facto de se tratar de um ato transformacional, segundo o qual um texto A (o hipertexto) deriva de um discurso predecessor (hipotexto), sem o qual não poderia ser o mesmo (GENETTE, 1982, p. 13). Ora, este princípio transformacional está patente no poema "Os balcões sucessivos sobre o rio”, no qual é possível confirmar o grau de importância da influência de textos anteriores na produção poemática de Ruy Belo, facto para o qual o poeta não cessava de chamar a atenção, de forma aberta, desprendida, por vezes irónica, dando pistas para a verdadeira compreensão da sua poesia como busca incansável da síntese entre a tradição e o talento individual:

Aos mais especializados domínios, aos mais variados setores, pode o poeta pedir emprestada a sua linguagem para depois a exibir, já sem esforço aparente, no poema, esse fruto de conquista laboriosa e sempre demorada porque, quanto mais de jato tiver saído, mais anos de vida terá custado. [...] A nós, portanto, as mais diversas influências. E que nos venham depois dizer que as tivemos. "Cá me queria parecer?" pensaremos. (BELO, 2002, p. 286)

O cotejo em anexo a este estudo, que resulta de uma pesquisa exaustiva - uma vez que o poeta não consente pistas que desvendem de imediato as suas influências -, demonstra que "Os balcões sucessivos sobre 
o rio" é efetivamente um poema hipertextual, que estabelece um claro diálogo com o romance de Agustina Bessa-Luís, O Manto, o seu principal hipotexto. $\mathrm{O}$ poeta terá partido da leitura da obra para a criação, numa fase inicial, de um repertório vocabular, que desejava amplo, inesperado, diversificado. $\mathrm{O}$ material recrutado não abrange a totalidade do romance. Situa-se entre as páginas 179 e 292 e foi utilizado de forma não sequencial, verificando-se avanços e recuos de páginas, por vezes significativos, o que demonstra que o poema terá sido composto ao sabor das necessidades compositivas exercidas pela pulsão das palavras, que se impunham e determinavam a dinâmica das suas contiguidades. Foram, assim, excisadas palavras e segmentos que, em si mesmos, desenraizados do seu contexto precedente, não eram mais do que matéria verbal descontínua e sem qualquer amplitude térmica. Esta profusão de materiais à disposição do poeta foi posteriormente alvo um árduo e implacável trabalho de seleção, de renúncia e de recriação, com a finalidade de fazer surgir vizinhanças e combinatórias inesperadas, geradoras de um forte impacto estético.

É possível observar que, n'“Os balcões sucessivos sobre o rio”, são utilizados pelo poeta diversificados mecanismos compositivos, tendo sempre em vista uma estética da intensidade e da energeia. No princípio do poema, verifica-se uma opção pela montagem de segmentos excisados, explorando-se contiguidades imprevistas e ruturas abruptas que proporcionam poderosos efeitos na temperatura da expressão. No entanto, convém notar que "Os balcões sucessivos sobre o rio" não é um poema-montagem. Ruy Belo não compõe "com luvas nas mãos prolongadas por instrumentos esterilizados", de forma "assética" (2002, p. 322). Na maior parte das situações, os segmentos enxertados são alvo de uma intervenção por parte do poeta, que, utilizando um conjunto de processos transformacionais, procura obter um novo artefacto de elevada voltagem poética e estética. Como já se referiu, o seu objetivo é sempre o de procurar superar o texto predecessor e despoletar "emoções quentes" (2002, p. 322), como é possível confirmar no cotejo apresentado em anexo entre o hipotexto agustiniano e o hipertexto. De facto, verifica-se que o poeta analisa atentamente o material recolhido, observa-o nos seus diferentes ângulos, deteta-lhe as rugosidades, as asperezas e experimenta 
novas abordagens, voltando a moldar o segmento, sujeitando-o ao torno, dando-lhe diferente curvatura, para o colocar em contextos outros que realçam o seu impacto rítmico-emotivo. Leves toques, por vezes, que rejeitam, substituem ou afinam e elevam de imediato a temperatura da expressão, como se pode observar no seguinte exemplo:

\begin{tabular}{l|l} 
Hipotexto O Manto, Agustina BessaLuís & $\begin{array}{l}\text { Hipertexto "Os Balcões Sucessivos sobre } \\
\text { o Rio", Ruy Belo }\end{array}$ \\
\hline $\begin{array}{l}\text { “... tesouras de poda aplicadas nas } \\
\text { roseiras" }\end{array}$ & "as tesouras da poda nas roseiras"
\end{tabular}

Com a excisão do vocábulo "aplicadas", o segmento adquire de imediato outra projeção e vibração. Um efeito de ambiguidade emerge agora do verso. Por um lado, sugere que as tesouras repousam sobre as roseiras, no vigor da sua plena floração, como se lá tivessem sido esquecidas. No entanto, este utensílio cria uma certa dissonância na beleza do quadro, pois evoca, como um pressentimento, a efemeridade, o declínio e a morte do que é expressão do belo e da alegria. $O$ verso remete ainda para uma outra leitura, a do som das tesouras da poda em atividade, em pleno outono, amputando o que fora outrora vigor e florescência, mas se tornou expressão da passagem do tempo, madeira envelhecida e morta que a lâmina suprime. A opção do poeta na substituição da preposição simples ("de") pela preposição contraída ("da”) cria um efeito de eco com a palavra subsequente: " $d a$ poda". Este toque subtil contribui para reforçar a musicalidade do verso, agora novamente torneado.

O trabalho hipertextual do autor está igualmente presente na estratégia de codificação do discurso a que já se fez referência, daí a valorização da ambiguidade e de outros mecanismos ao serviço da obscuritas, presentes em vários momentos do poema, e que amplificam a sua ressonância enigmática. A afirmação "é esse o meu convite à desistência" desperta no leitor a dúvida, dado o seu sentido nebuloso. Os versos anteriores nada esclarecem e os seguintes dão continuidade ao sentimento de desorientação e de perplexidade: "a pena menos pública do mundo nos / lagos das finas flores dos sabugueiros”. Embora intuitivamente se consiga 
aceder a uma interpretação desta composição poemática, a verdade é que apenas o conhecimento do hipotexto permitirá ao leitor desvendar os enigmas que o texto lhe apresenta e com os quais o desafia continuamente.

A justaposição de fragmentos é um outro mecanismo utilizado pelo poeta para promover essa codificação do discurso. No poema, a maiúscula é utilizada como indicação do princípio da fronteira de um fragmento. Esta composição está, por conseguinte, dividida em 12 secções de extensão desigual, oscilando entre um único verso e 10 versos. Os fragmentos que a constituem foram dispostos segundo os mesmos princípios, o da descontinuidade e da imprevisibilidade, dispositivos que acentuam o seu impacto estético. É importante notar que, em alguns fragmentos, se verifica a sucessão de versos em que está ausente a forma verbal, dandose prevalência ao nome e ao adjetivo. Este mecanismo compositivo deteta-se logo no princípio do poema e em vários outros momentos:

Os balcões sucessivos sobre o rio as tesouras de poda nas roseiras a sonolência lânguida e perversa esse todo coerente e sobre ele apenas a abóbada da minha perfeição

$[\ldots]$

os cheiros confortáveis e antigos imagens dum lirismo fraudulento um conforto algum tanto apreensivo [...

leitura de discursos no outono na casa abandonada e submetida à chuva $[\ldots]$ sorrisos de mulheres sobre a areia [... os sinos vesperais nos dias de verão o cão que passa numa encruzilhada [...

a minha saudação aos infantes do medo ${ }^{3}$ 
A combinatória destas imagens destituídas de verbo, que se sucedem de forma imprevista, confere uma ritmicidade muito própria ao poema e proporciona uma maior vivacidade da expressão, fazendo-se ressaltar os sons, os "cheiros", a visualidade do que é progressivamente evocado.

Porém, outros mecanismos transformacionais do material excisado são utilizados pelo poeta e permitem observar a medição de forças com o autor que leu e o influenciou:

\begin{tabular}{|c|c|}
\hline Hipotexto O Manto, Agustina BessaLuís & $\begin{array}{l}\text { Hipertexto "Os Balcões Sucessivos sobre } \\
\text { o Rio", Ruy Belo }\end{array}$ \\
\hline $\begin{array}{l}\text { "[...] sono mais triste e mais perverso - } \\
\text { o sono de si mesmo, o esquecimento do } \\
\text { próprio ser }[\ldots] .\end{array}$ & "a sonolência lânguida e perversa" \\
\hline $\begin{array}{l}\text { "À beira do rio Ave, }[\ldots] \text { desembarcam as } \\
\text { lavadeiras com os seus lenços verdes, que } \\
\text { cheiram a fumo de pinheiro, atados para } \\
\text { a nuca." }\end{array}$ & $\begin{array}{l}\text { e meto então um lenço num dos bolsos } \\
\text { que cheira ao perfume dos pinheiros }\end{array}$ \\
\hline
\end{tabular}

No primeiro exemplo, a substituição, no hipertexto, de "sono" por "sonolência" e de "triste" por "lânguida" acentua a ideia de entorpecimento, de narcose do sentir e do existir, traduzindo de forma mais límpida o "sono de si mesmo" expresso no hipotexto. Os vocábulos meticulosamente escolhidos pelo poeta, "sonolência" e "lânguida", criam igualmente um jogo com as variações tímbricas das vogais nasais ${ }^{4}$, a que se acumulam outros ecos, utilizados nos versos anteriores e nos seguintes, nomeadamente a valorização dos sons sibilantes ("sucessivos", "tesouras", "roseiras”, "sonolência”, "perversa”, “esse”, “desistência”). A substituição feita pelo poeta resultará igualmente num efeito de estranheza, uma vez

$4 \quad$ Veja-se também o verso: “um conforto algum tanto apreensivo" (2014, p. 817). 
o segmento "sonolência lânguida" criou uma contiguidade inesperada com o vocábulo "perversa”. Todavia, a vizinhança destas palavras acaba por intensificar a negatividade desse sentimento de torpor e por elevar a temperatura da expressão. Na segunda situação, verifica-se que o mesmo vocábulo, "lenço", é colocado num contexto diferente, alterando-se de imediato o seu sentido no hipertexto. Por outro lado, o "fumo de pinheiro" é convertido em "perfume dos pinheiros", uma espécie de subversão irónica que acaba por amplificar o efeito estético e poético do verso.

Em vários momentos do poema, é visível igualmente o recurso ao mecanismo do transporte, com importantes repercussões rítmicas, pois a não coincidência entre a unidade da sintaxe e o limite do verso provoca quebras abruptas da integridade da frase, deixando isolados e em suspenso na fronteira dos versos preposições simples ou contraídas: "a pena menos pública do mundo nos"; "vinha com o vestido cor magenta nos"; "mas só de noite desço até ao mar após"; "Não quero nada quero estar presente sobre". Este dispositivo é, nos casos apontados, mais um dos mecanismos intensificadores do impacto poético e estético da composição em análise.

No confronto entre hipotexto e hipertexto, observa-se igualmente que o poeta transforma a categoria estética do feio, to aischron, em expressão do Belo, utilizando o mesmo repertório vocabular:

\begin{tabular}{|c|c|}
\hline Hipotexto O Manto, Agustina BessaLuís & $\begin{array}{l}\text { Hipertexto "Os Balcões Sucessiv } \\
\text { sobre o Rio", Ruy Belo }\end{array}$ \\
\hline $\begin{array}{l}\text { "Pura envergava o seu vestido de cor } \\
\text { magenta }[\ldots] \text {. Ela deixava soltos os } \\
\text { cabelos, que lhe chegavam à cintura; } \\
\text { tinha o ar de tal maneira inesperado, que } \\
\text { despertava o riso dos jovens }[\ldots] \text {." }\end{array}$ & $\begin{array}{l}\text { Ela tinha um aspecto inesperado } \\
\text { vinha com o vestido cor magenta nos } \\
\text { braços que lhe cresceram sobre a terra }\end{array}$ \\
\hline $\begin{array}{l}\text { “[... havia uma rapariga de cabelos } \\
\text { como víboras negras e compridos braços } \\
\text { de bailarina; andava devagar, sacudia-se } \\
\text { como uma barca, sabia mover-se como já } \\
\text { ninguém sabe }[\ldots] \text {." }\end{array}$ & movia-se ao andar como uma barca \\
\hline
\end{tabular}


No hipotexto agustiniano, o "ar inesperado" da personagem feminina está associado ao ridículo, uma vez que essa característica singular desencadeia o riso nos jovens que a observam. Em contrapartida, no hipertexto, o caráter "inesperado" da mulher surge associado à sua participação do Belo, reforçado pela vivacidade da cor do seu vestido e pela forma harmoniosa de se mover. No segundo exemplo, Ruy Belo usou a mesma estratégia transformacional. De facto, no romance de Agustina Bessa-Luís, a "rapariga” (e não a "mulher”) é marcada pela desproporção e pela repulsa. Os seus cabelos como "víboras negras” lembram a cabeça da Górgone, esse mundo do horrendo. Os seus braços evocavam a figura de uma bailarina, contudo, eram "compridos", característica que remete para a ideia de deformidade. Por fim, o seu corpo "sacudia-se como uma barca”, forma verbal que retira harmonia ao movimento e remete para o impulso serpeante. No entanto, o poeta preserva a sua graciosidade e reforça-a, sublinhando a suavidade da ondulação da "barca" e associando, desta forma, a mulher às águas maternais, ao estado de suspensão de quem as habitou no princípio do mundo.

Uma multiplicidade de outros dispositivos são utilizados para elevar a vivacidade e a temperatura da expressão, nomeadamente: o paralelismo ("Espero por alguém espero pelo sol”); a aliteração ("finas flores"; "pesar de pálpebras"); o jogo com os timbres vocálicos ("pena menos pública"); a antítese ("Não quero nada quero"); entre outros. De salientar que não é objeto deste estudo uma análise exaustiva dos processos transformacionais utilizados pelo poeta. Procurou-se apenas apontar alguns dos mecanismos experimentados por Ruy Belo nesse laborioso trabalho sobre a linguagem e sobre as suas virtualidades compositivas. De facto, partindo de uma amálgama de material excisado que, isoladamente, não era mais do que um amontoado de palavras e segmentos, o poeta conseguiu criar um novo artefacto artístico, no qual é visível a medição de forças e a tentativa de superação do discurso predecessor, a fim de, desta forma, conquistar a singularidade de uma voz própria. 
É importante realçar que o diálogo hipertextual entre "Os balcões sucessivos sobre o rio" de Ruy Belo e a obra de Agustina Bessa-Luís, $O$ Manto, permite aceder a um plano mais profundo de entendimento do poema e desvendar o seu caráter enigmático. $\mathrm{O}$ pleno conhecimento do romance agustiniano permite concluir que o poema se debruça sobre a mesma problemática, a do mal. O homem contemporâneo ("sou um contemporâneo") desistiu de tudo ("é esse o meu convite à desistência"s) e vive o adormecimento de uma existência sem propósito. A apatia atravessa o poema. Os seus sintomas são semeados gradualmente e revelam um sujeito perdido na sua própria alienação. Os ruídos do tempo presente, os aromas, o movimento, a rotação dos dias, asseguram-no de que ainda pertence ao aqui e agora, e ajudam-no a esquecer o medo do imponderável, horizonte inescapável de que o sujeito se procura evadir. Recolhendo-se a uma existência que se cinge ao simples estar no tempo e ao ato de olhar, assistindo como um espectador aos embates da história, o sujeito em fuga para a frente cessa o constante estado de vigília a que a inquietude da ameaça o forçava e rende-se à "sonolência lânguida e perversa" de um entorpecimento existencial.

Os balcões sucessivos são, por conseguinte, patamares, não de ascensão, mas de queda progressiva. Desde o ponto em que se encontra, o olhar do sujeito desce até à escuridão de um rio que fervilha implacável, esperando a sua queda na inevitabilidade.

A alternância entre verbos no presente do indicativo e verbos no pretérito perfeito e imperfeito vai esboçando uma oposição entre um tempo antigo e o presente em que o sujeito está ancorado. As raras ocorrências dos verbos que remetem para o passado prendem-se com a evocação da mulher, como árvore cujos ramos protetores cresceram acima da terra ou cujo andar, balouçado como de barca, lembra o conforto assegurador das águas matriciais, a infância embalada nesse doce ritmo

BELO, 2014, p. 818 e 817, respetivamente. 
("coisas que desde a infância a construíam"). O passado liga-se, então, a um tempo que era abrigo, alegria e ausência de vulnerabilidade do sujeito. O contexto tutelar reforçava-o e validava-o. Porém, abriramse-lhe os olhos para a visão do mal: esse "mundo de medos e animais / onde abri os olhos para a luz de agora" (BELO, 2014, p. 818). Na perspetiva de Lytta Basset, "naître est par définition être exposé au mal [...]" (2002, p. 78). Tratase, portanto, de um mal de que o homem não mais se poderá libertar. $\mathrm{O}$ "agora" é a consciência da irreversibilidade e da finitude, da degradação de tudo o que é material, da perda dos lugares da alegria, da permanente inquietação e vigilância. Os "infantes do medo" nascem dessa experiência traumática, depois da qual não mais serão os mesmos. $\mathrm{O}$ sujeito poético saúda-os ("a minha saudação aos infantes do medo") (BELO, 2014, p. 818), a esses que, num passado muito recente, conheciam a inocência e a alegria da infância, mas que foram traídos e atirados sem aviso para os abismos da precariedade humana e da sua irremediável solidão.

Esta saudação adquire pleno significado quando é considerado o diálogo com o hipotexto $O$ Manto. Na verdade, no romance agustiniano, narra-se a romaria de São Bartolomeu do Mar, em especial o banho dos infantes, espectáculo do terror humano, na sua luta milenar contra as manifestações do mal, que se tenta pacificar e exorcizar através dos "três mergulhos rituais que preservam do medo" e que, em tempos remotos, se destinavam a expurgar o "mal sagrado", a epilepsia. Porém, esta tradição alastrou para a exorcização de outras formas de sobressalto e de "visão do inferno" (BESSA-LUÍS, s/d). O choro afogado das crianças, mergulhadas três vezes na envolvência tumular das águas pelos sargaceiros, fá-las regressar dos abismos com uma nova lucidez. O "coro de gritos" revela a "tensão do terror" após este acontecimento traumático, que as transformará definitivamente, pois deu-lhes a conhecer o pressentimento do mal. $\mathrm{E}$ os infantes do medo choram a sua inocência. Transidos, conhecem o desespero, o espanto pela ofensa do abandono, entregues pelo "pai ou a irmã” (s/d, p. 214) a mãos desconhecidas que os lançam sem aviso à força abissal das águas. A intranquilidade pautará doravante a sua existência. 
Os "infantes do medo" evocados nesta composição poemática são, assim, a metáfora da própria humanidade, unida num medo comum, o do sofrimento e da morte. O sujeito poético saúda, por isso, os seus semelhantes. Tal como eles, é aquele que vive em sobressalto, porque conhece a presença do imponderável que inflige no humano um padecimento não passível de ser medido. A melhor forma de sobreviver está patente no seu "convite à desistência", definido lapidarmente no verso: "sou um contemporâneo assisto a tudo". Ser espectador, escolhendo a destruição da vontade e do sentir, constitui, efetivamente, a única fuga de um constante sentimento de inquietude, de ameaça, de vigilância, num universo sentido como hostil e sem abrigo.

Apesar de tudo, o uso do presente do indicativo nesta composição poemática está também associado àquilo que traz um "um conforto algum tanto apreensivo", porque efémero e precário. Na verdade, todos os sentidos do sujeito assistem às manifestações do belo: as "roseiras", o rio "sob balcões sucessivos", as "flores dos sabugueiros" espelhadas nos lagos, o "mar", a "hora crepuscular", os "sorrisos de mulheres", o sol, a "floração da primavera", as "dunas" que antecedem os "pinhais", a "terra branca", as "madrugadas do sargaço". Também os sons povoam o presente: o das águas desse rio que corre inexorável, os "sinos vesperais", as investidas dos "ventos". Diferentes aromas chegam igualmente à "sensibilidade das narinas": a fragrância das "roseiras", os "cheiros confortáveis e antigos", o "perfume dos pinheiros". Também o sabor do verão, que se frui na "doçura" da laranjeira, participa dessa manifestação do belo.

Com ele coexistem o inexplicável e o calafrio, que assombram e ensombram esse presente e mostram a proximidade do mal. $\mathrm{O}$ cão que "passa numa encruzilhada", o cântaro que "racha inexplicavelmente", os ventos que "sopram agonias" constituem esse mundo de "medos e animais" no qual o sujeito poético, tal como $\mathrm{Job}^{6}$, abriu os seus olhos, conhecendo o excesso de mal e experienciando uma aguda solidão existencial. Consciente

Depois de sofridas todas as provações, Job quebrou um longo silêncio de sete dias e sete noites e amaldiçoou o dia em que nasceu, fazendo referência à visão da "miséria", esse mal no mundo, quando foi dado à luz: "Porque não fechou as portas do ventre / para esconder à minha vista tanta miséria” (Jb 3: 10, GORGULHO, 2015). 
desta realidade que não mais conseguirá esquecer, apesar do convite à desistência e do desejo de entorpecimento do sentir, o sujeito poético vive em permanente conflito e vacilação ("mudo de opinião continuamente"), daí a sua fidelidade à tristeza, uma tristeza profunda cujas manifestações percorrem esta composição poemática, nomeadamente no desejo de solidão ("deixem-me só") e no estado de permanente angústia e sobressalto ("Ave de alarme sou"). A tristeza expressa-se, por fim, nessa passividade, a que já se fez referência, de quem abdica de agir historicamente e se limita a assistir e a esperar. No entanto, trata-se de uma espera de quem nada espera e nada quer ("não quero nada") senão apenas ser inteiramente presente, momentâneo e fragmentado, desligando cada instante daquele que o precedeu para se poder libertar da consciência da fugacidade do tempo e do mal de pensar. $\mathrm{O}$ mal de pensar no mal, o mal da lucidez face à sua vizinhança ameaçadora.

Assim, este esperar não é o esperar da esperança, mas da expetativa despojada e sem inquietude de quem aguarda o que sabe que regressará: "espero o teu regresso pela tarde", assim como espera "pelo sol", pela "floração da primavera", por essa rotatividade do "curso do dia e da noite", que cria uma circularidade asseguradora e confortante, ocultando a vidência e a violência do mal. Sem desejo, porque este cria a falsa expetativa na eternidade de algo que está condenado a perecer, sem vontade de habitar historicamente o tempo, imerso na tristeza e reduzindo-se apenas a "estar presente", o sujeito aguarda a passagem do tempo que se renova e traz a terra da alegria, fazendo-o esquecer, ainda que temporariamente, o medo da morte, a solidão existencial humana. No entanto, se a temporalidade cíclica é evocada por várias vezes ao longo do poema, mesmo nesse movimento da barca que baloiça, associado à mulher, o rio "sob os balcões sucessivos" representa a ameaça, ameaça anunciada no título desta composição poemática que introduz o último livro de Ruy Belo. As águas que correm inexoráveis, numa fuga implacável para a frente, não deixam esquecer a despedida dessa terra da alegria, o abandono do homem à hostilidade de um universo indiferente e incompreensível.

ANEXO - Cotejo entre hipertexto e hipotexto 


\begin{tabular}{|c|c|}
\hline $\begin{array}{l}\text { Ruy Belo, “Os Balcões Sucessi- } \\
\text { vos sobre o Rio” }\end{array}$ & Agustina Bessa-Luís, O Manto \\
\hline "Os balcões sucessivos sobre o rio & $\begin{array}{l}\text { "Pela ladeira, que era composta de balcões } \\
\text { sucessivos sobre o rio, os olhos de Álvaro Teles } \\
\text { não paravam nunca." (p. 202) }\end{array}$ \\
\hline as tesouras da poda nas roseiras & $\begin{array}{l}\text { “[... ela tremia e atravessava depressa para ir ao } \\
\text { encontro }[\ldots] \text { dos familiares sons de campainhas, } \\
\text { de ganidos de cachorros, de tesouras de poda } \\
\text { aplicadas nas roseiras." (p. 203) }\end{array}$ \\
\hline $\begin{array}{l}\text { a sonolência lânguida e perversa } \\
\text { esse todo coerente e sobre ele } \\
\text { apenas }\end{array}$ & $\begin{array}{l}\text { “[... ] não cair no sono mais triste e mais perverso } \\
\text { - o sono de si mesmo, o esquecimento do próprio } \\
\text { ser }[\ldots] . ”(\text { p. } 200)\end{array}$ \\
\hline a abóbada da minha perfeição & $\begin{array}{l}\text { “[...] o pobre não está no mundo para completar } \\
\text { a abóbada da sua perfeição." (p. 201) }\end{array}$ \\
\hline é esse o meu convite à desistência & $\begin{array}{l}\text { “ }[\ldots] \text { ia para velha e doía-lhe o silêncio como } \\
\text { um abandono, um convite à desistência }[\ldots] . " \text { (p. } \\
\text { 202-203) }\end{array}$ \\
\hline $\begin{array}{l}\text { a pena menos pública do mundo } \\
\text { nos }\end{array}$ & $\begin{array}{l}\text { "É como que o convento das insignificâncias, o } \\
\text { horto da pena menos pública do mundo - que é } \\
\text { a de viver a sós com os seus restritos meios }[\ldots] \text {." } \\
\text { (p. 186) }\end{array}$ \\
\hline $\begin{array}{l}\text { lagos das finas flores dos } \\
\text { sabugueiros } \\
\text { onde a mulher soltava os cabelos } \\
\text { pra que neles se prendesse o } \\
\text { cheiro a erva }\end{array}$ & $\begin{array}{l}\text { "Pura, que todos os dias era capaz de julgar-se } \\
\text { perto dum lago onde boiavam as finas flores dos } \\
\text { sabugueiros e que soltava os cabelos para que } \\
\text { neles se prendesse o cheiro da erva }[\ldots] \text {, sabia que } \\
\text { nada daquilo era outra coisa senão a sua realidade } \\
\text { [...]." (p. 187) }\end{array}$ \\
\hline
\end{tabular}




Ruy Belo, “Os Balcões Sucessi-
vos sobre o Rio”
Ela tinha um aspecto inesperado
vinha com o vestido cor magenta
nos

braços que lhe cresceram sobre a terra

movia-se ao andar como uma barca

Importa-me é o curso do dia e da noite

Vou andar um bocado nos caminhos é pela hora em que não há ninguém

nudez desprevenida dos meus dias

mas só de noite desço até ao mar após
Agustina Bessa-Luís, O Manto

"Pura envergava o seu vestido de cor magenta [...]. Ela deixava soltos os cabelos, que lhe chegavam à cintura; tinha o ar de tal maneira inesperado, que despertava o riso dos jovens $[\ldots] . "$ (p. 184)

“[...] morreu, os braços cresceram sobre a terra, [... com a sensualidade frugal e profunda duma árvore que se agita.” (p. 185)

“[... ] havia uma rapariga de cabelos como víboras negras e compridos braços de bailarina; andava devagar, sacudia-se como uma barca, sabia mover-se como já ninguém sabe [...].” (p. 185)

"Não sabia porquê, o curso do dia e da noite interessava-lhe muitíssimo [...].” (p. 179)

"Venha sair comigo, venha andar um bocado nos caminhos, a esta hora não se vê ninguém." ( $\mathrm{p}$. 182)

“[... ] sentia prazer em despi-las assim à distância para olhar friamente a sua nudez desprevenida $[\ldots]$.. (p. 182)

"Mas só de noite ele descia, e então todas as precauções até aí observadas eram postas de parte $[\ldots]$... (p. 180) 


\begin{tabular}{|c|c|}
\hline $\begin{array}{l}\text { Ruy Belo, “Os Balcões Sucessi- } \\
\text { vos sobre o Rio” }\end{array}$ & Agustina Bessa-Luís, $O$ Manto \\
\hline $\begin{array}{l}\text { as sete horas da tarde hora } \\
\text { crepuscular }\end{array}$ & $\begin{array}{l}\text { “[... trouxessem-lhe uma histérica professora } \\
\text { que expande as suas lágrimas às sete horas da } \\
\text { tarde, na hora crepuscular }[\ldots] \text {... (p. 198) }\end{array}$ \\
\hline os cheiros confortáveis e antigos & $\begin{array}{l}\text { “[... pensavam na casa materna }[\ldots] \text {, naquele } \\
\text { cheiro de fumo, de resina que arde, de bosta } \\
\text { quente trazida em cestos para calafetar o forno } \\
\text { do pão. Cheiros confortáveis e antigos }[\ldots] \text {.. (p. } \\
\text { 196) }\end{array}$ \\
\hline imagens dum lirismo fraudulento & $\begin{array}{l}\text { “[... palavras vãs e imagens dum lirismo } \\
\text { fraudulento." (p. 190) }\end{array}$ \\
\hline $\begin{array}{l}\text { um conforto algum tanto } \\
\text { apreensivo }\end{array}$ & $\begin{array}{l}\text { “[... era uma mão áspera, quente e que } \\
\text { comunicava um conforto um tanto apreensivo.” } \\
\text { (p. 188) }\end{array}$ \\
\hline $\begin{array}{l}\text { coisas que desde a infância a } \\
\text { construíam }\end{array}$ & $\begin{array}{l}\text { “[... as tardes de chuva }[\ldots] \text { inspiravam o desejo } \\
\text { de pequenas recordações, de falar da infância, } \\
\text { de dizer coisas há muito perdidas, como }[\ldots] \text { as } \\
\text { travessuras dos irmãos }[\ldots] \text {.. (p. 193) }\end{array}$ \\
\hline Mudo de opinião continuamente & $\begin{array}{l}\text { "Álvaro Teles }[\ldots] \text { Era um homem incoerente, } \\
\text { que mudava continuamente de opiniões }[\ldots] . " \\
\text { (p. 203) }\end{array}$ \\
\hline espero o teu regresso pela tarde & $\begin{array}{l}\text { “[... com que desastrado susto ele esperava o } \\
\text { seu regresso à tarde }[\ldots] . ”(\text { p. 207-208) }\end{array}$ \\
\hline
\end{tabular}




Ruy Belo, “Os Balcões Sucessi-
vos sobre o Rio”
e cuidadosamente velo a minha
cólera

A vida é para mim pesar de pálpebras

leitura de discursos no outono na casa abandonada e submetida à chuva

\section{Regresso afinal aos próprios}

\section{hábitos}

sorrisos de mulheres sobre a areia

sou fiel à tristeza e pouco mais

e meto então um lenço num dos bolsos que cheira ao perfume dos pinheiros
Agustina Bessa-Luís, O Manto

"E a sua cólera, como uma represa que se abre, saía dele então, como víboras $[\ldots] ;[\ldots]$ essa cólera cuja lembrança the passava depressa, mas sobre a qual ela velava cuidadosamente [...].” ( $\mathrm{p}$. 208)

"Com a idade simplificou-se bastante $\boldsymbol{a}$ sua vida em comum, $[\ldots]$ o campo, o pingar da água no tanque $[. .$.$] , lhe davam uma moleza, um pesar de$ pálpebras que a obrigavam a recolher-se muito cedo [...].” (p. 208-209)

“[...] se elas retomavam afinal os seus próprios hábitos, desiludidas com aquele método enfático demais para uma brincadeira $[\ldots]$, ele sofria.” (p. 210)

"À beira do rio Ave, $[\ldots]$ desembarcam as lavadeiras $[. .$.$] . São mulheres prazenteiras, que$ riem, e cujas vozes enchem o ar e as margens de $\operatorname{areia}[\ldots] . ”($ p. 210)

"Gostava de julgar-se ocupado em amá-las, [... para nelas experimentar o que em si próprio estava em vez de uma fé - a fidelidade da tristeza e o recurso da vontade não evoluída." (p. 210)

"À beira do rio Ave, $[\ldots]$ desembarcam as lavadeiras com os seus lenços verdes, que cheiram a fumo de pinheiro, atados para a nuca." (p. 210) 


\begin{tabular}{|c|c|}
\hline $\begin{array}{l}\text { Ruy Belo, “Os Balcões Sucessi- } \\
\text { vos sobre o Rio” }\end{array}$ & Agustina Bessa-Luís, $O$ Manto \\
\hline Ave de alarme sou deixem-me só & $\begin{array}{l}\text { “[...] de facto lhe desagradava estar só com } \\
\text { Gracia. }[\ldots] \text { A rapariga }[\ldots] \text { Andava em volta } \\
\text { de Marcelo como uma ave de alarme, prevenia-o } \\
\text { sem lhe falar }[\ldots] \text {. (p. 231-232) }\end{array}$ \\
\hline $\begin{array}{l}\text { sou um contemporâneo assisto } \\
\text { a tudo }\end{array}$ & $\begin{array}{l}\text { “[... e ela assistia, no seu lugar de } \\
\text { contemporânea, a uma generosidade infinita } \\
{[\ldots] . "(\text { p. 233) }}\end{array}$ \\
\hline $\begin{array}{l}\text { os sinos vesperais nos dias de } \\
\text { verão }\end{array}$ & $\begin{array}{l}\text { "O medo }[\ldots] \text { anda à solta, balança-se nos sinos } \\
\text { vesperais }[\ldots] . " \text { (p. 213) }\end{array}$ \\
\hline $\begin{array}{l}\text { o cão que passa numa } \\
\text { encruzilhada }\end{array}$ & $\begin{array}{l}\text { “O diabo enfarruscado }[\ldots] \text { é o medo, assim } \\
\text { como é }[\ldots] \text { o cão que passa numa solitária } \\
\text { encruzilhada }[\ldots] \text {." (p. 213) }\end{array}$ \\
\hline $\begin{array}{l}\text { um cântaro que racha } \\
\text { inexplicavelmente }\end{array}$ & $\begin{array}{l}\text { “[... raparigas que voltam da fonte, com o } \\
\text { seu cântaro de barro poroso que, de repente, } \\
\text { inexplicavelmente, se abre de alto a baixo." (p. } \\
213-214)\end{array}$ \\
\hline confundido no hálito do mar & $\begin{array}{l}\text { “Confundia-se o hálito do mar com o chuvisco } \\
\text { vindo das serras }[\ldots] . "(\text { p. } 214)\end{array}$ \\
\hline $\begin{array}{l}\text { a minha saudação aos infantes do } \\
\text { medo }\end{array}$ & $\begin{array}{l}\text { “[... então brotam as lágrimas }[\ldots] \text { e os infantes } \\
\text { do medo deixam-se agasalhar e vestir com um } \\
\text { espanto }[\ldots] \text { que toda a vida hão-de trazer no } \\
\text { peito." (p. } 218)\end{array}$ \\
\hline
\end{tabular}




\begin{tabular}{|c|c|}
\hline $\begin{array}{l}\text { Ruy Belo, “Os Balcões Sucessi- } \\
\text { vos sobre o Rio” }\end{array}$ & Agustina Bessa-Luís, $O$ Manto \\
\hline crianças que iniciam o andar & $\begin{array}{l}\text { “[... }] \text { como crianças que iniciam a descoberta do } \\
\text { andar }[\ldots] . "(\text { p. 217) }\end{array}$ \\
\hline Espero por alguém espero pelo sol & $\begin{array}{l}\text { “Esperar o sol é um mester de gente ocupada com } \\
\text { grande trânsito de ideias. [...] Esperar o sol, eis } \\
\text { uma ocupação de reis e de filósofos e de gente } \\
\text { secreta." (pp. 240-241) }\end{array}$ \\
\hline pla doçura estival da laranjeira & $\begin{array}{l}\text { “[... era esse um cheiro profundo, }[\ldots] \text { a doçura } \\
\text { estival da laranjeira }[\ldots] . "(\text { p. } 257)\end{array}$ \\
\hline $\begin{array}{l}\text { ando pelos caminhos muito } \\
\text { tempo }\end{array}$ & $\begin{array}{l}\text { "Eram duas meninas a quem a orfandade fazia } \\
\text { como que um pouco assombradas; andavam } \\
\text { pelos caminhos muito tempo }[\ldots] . \text {.. (p. 246) }\end{array}$ \\
\hline $\begin{array}{l}\text { e passo pelas portas devassadas } \\
\text { pelos ventos } \\
\text { em cujos gonzos sopram agonias }\end{array}$ & $\begin{array}{l}\text { “Portas de agonias e de ventos [...] perante as } \\
\text { quais, no entanto, se sente uma emoção, como se o } \\
\text { sacrilégio nos doesse nas mãos, que não avançam } \\
\text { para tocar os velhos batentes e campainhas } \\
\text { cobertas de azebre!” (p. 288) }\end{array}$ \\
\hline $\begin{array}{l}\text { E espero de novo a floração da } \\
\text { primavera }\end{array}$ & $\begin{array}{l}\text { "Assim outros passam nos campos onde sucede a } \\
\text { floração da primavera, o veludo do tojo florido } \\
\text { [...]." (p. 292) }\end{array}$ \\
\hline $\begin{array}{l}\text { Não quero nada quero estar } \\
\text { presente sobre } \\
\text { as dunas do começo dos pinhais }\end{array}$ & $\begin{array}{l}\text { “- Nada; não querem nada. Estão só a ver... } \\
\text { - [... }] \text { Se não querem nada, porque olham assim } \\
\text { para cá?” (p. 246) }\end{array}$ \\
\hline
\end{tabular}




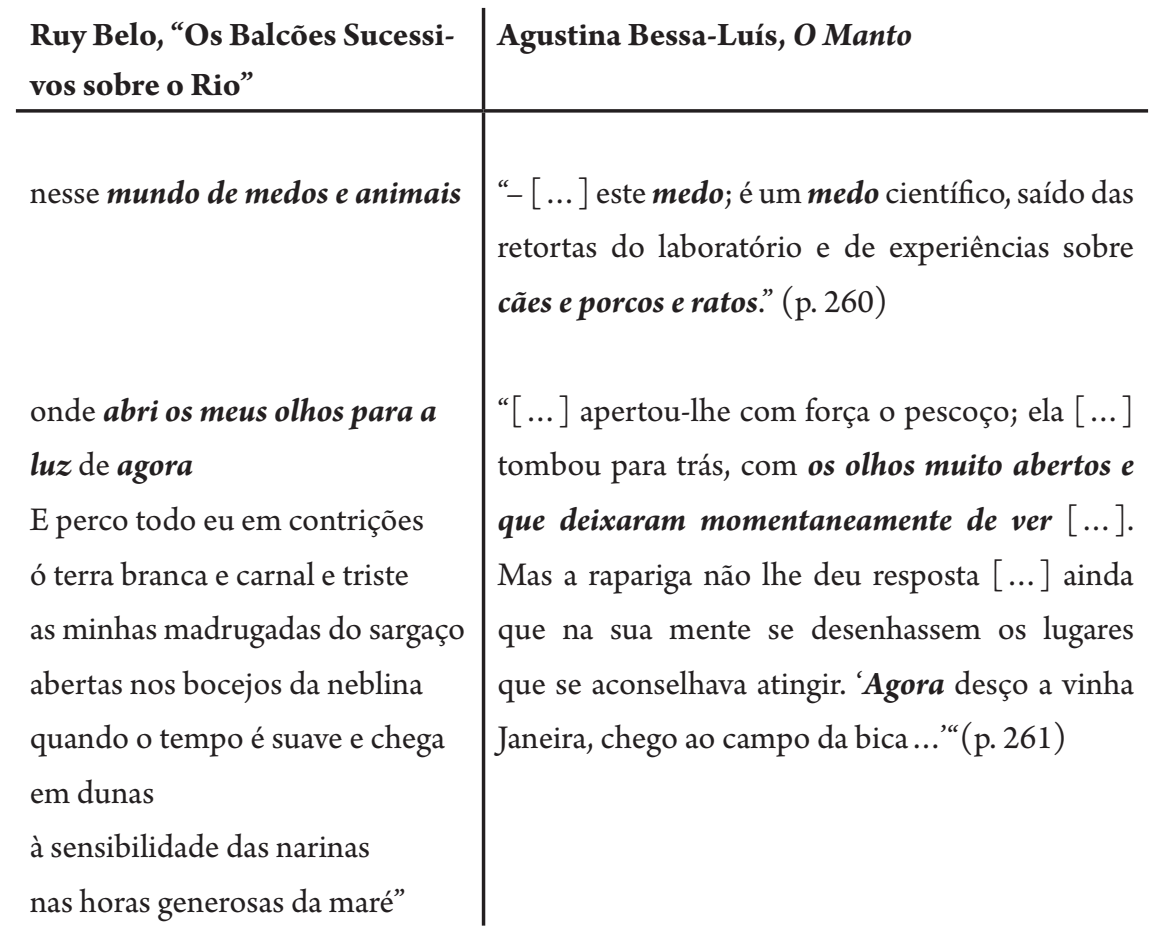

THe INFLUeNCE OR “Os BALCÕES SUCESSIVOS SOBRE O RIO” OF RUY BELO

Abstract

For Ruy Belo, the influence of tradition on the late poets is inevitable and one who seeks to find its singularity must be aware of this inescapable reality. In this paper, attention is focused on the author's hypertextual dimension, mainly on "Os balcões sucessivos sobre o rio", a composition that begins the last book written by Ruy Belo, Despeço-me da terra da alegria (1977), and that gives continuity to the compositional mechanisms and the main problems that characterize the magnificent long poem, A margem da alegria (1974).

KeYwords: Ruy Belo; influence; hypertextuality; evil. 
LA INFLUENCIA O “OS BALCões SUCESSIVOS SOBRE O RIO”, DE RUY BELO

\section{RESUMEN}

Para Ruy Belo, la influencia de la tradición en el poeta tardio es inevitable y quien busca su singularidade debe ser consciente de esta realidade inescapável. En este estudio, se analiza la dimensión hipertextual del autor, centrándose la atención principalmente en "Os balcões sucessivos sobre o rio", composición que introduce el último libro escrito por el poeta, Despeço-me da terra da alegria (1977), y da continuidad a los processos compositivos y problemas abordados en el magnífico poema largo, A margem da alegria (1974).

Palabras Clave: Ruy Belo; influencia; hipertextualidad; mal.

\section{REFERÊNCIAS}

SOARES, Ana Maria Pereira. A alegria e o mal em Ruy Belo: estudo da composição Hipertextual d'A Margem da Alegria. 2017. 733 f. Tese (Doutorado em Estudos Literários, Culturais e Interartísticos, Ramo de Literatura e Cultura - Teoria e Estéticas Literárias) - Faculdade de Letras da Universidade do Porto, Porto, 2017. BASSET, Lytta. Guérir du Malheur. Paris: Albin Michel / Labor et Fides, 2002. BELO, Ruy. Todos os poemas. Lisboa: Assírio \& Alvim, 2014.

. Na senda da poesia. Lisboa: Assírio \& Alvim, 2002.

BESSA-LUÍS, Agustina. O Manto. Lisboa: Bertrand, s/d.

ELIOT, T. S. Los poetas metafísicos y otros ensayos sobre teatro y religión. Buenos Aires: Emecé Editores, S. A., s/d.

GENETTE, Gérard. Palimpsestes : la littérature au second degré. Paris: Éditions du Seuil, 1982.

GORGUlHO, Gilberto da Silva et al. Bíblia de Jerusalém. São Paulo: Paulus, 2015.

HORÁCIO. Arte poética. Lisboa: Editorial Inquérito, 1984. 


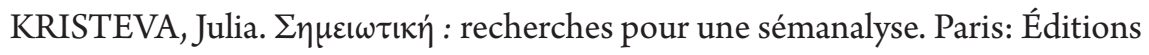
du Seuil, 1978.

Submetido em 07 de outubro de 2019

Aceito em 08 de janeiro de 2020

Publicado em 31 de maio de 2020 